\title{
Punishing Disposition: Sting Operations on the Internet
}

\author{
Jae Woong Shim*
}

School of Communication and Media, 52 Hyochangwon-gil, Yongsan-gu, Sookmyung Women's University, Seoul, Korea $140-742$

\begin{abstract}
Given the pervasiveness of illicit pornography on the Internet, pedophiles can easily and quickly access the objects of their sexual preferences, utilizing the unlimited potential of the Internet to lure an unprecedented number of victims. Meanwhile, unrestrained access to supposedly prohibited sites also makes it possible for law enforcement authorities to conduct sting operations designed to apprehend potential sexual criminals via the Internet. However, such strategy raises some legal problems because it heavily relies on one's dispositional aspects in capturing alleged sexual criminals. The lack of a clear definition of disposition makes the issue more complicated. The psychological findings on disposition may clarify the controversy over sting operations online, but less attention has been paid to psychological literature. Based on the review on disposition in psychology, the present study argues that current disposition-oriented court rulings on sting operation claims cannot be justified. Implications of this body of research for law and psychology are also considered.
\end{abstract}

Keywords: Online sting operation, dispositional psychology.

\section{INTRODUCTION}

The Internet has become the center of social concern as pedophiles attempt to use it to cater to their sexual proclivities (Beech, Elliott, Birgden, \& Findlater, 2008; Jones, 2007). Researchers point out that the Internet serves as a convenient connection to countless potential sexual victims and a medium of child exploitation (Abbott, 2002).

To prevent such sexual crimes targeted to the children in particular, law enforcement officers frequently conduct sting operations, which include undercover investigations designed to apprehend potential sexual criminals via the Internet (Gregg, 1996; Krone, 2004; Moore, Lee, \& Hunt, 2007). In a typical sting operation, a law enforcement officer poses as a participant or a prospective victim in unlawful activities (Hay, 2005). With the help of the Internet, law enforcers working to capture sex criminals can observe illegal online activities, such as searches for child pornography or online seduction of children (Quayle \& Taylor, 2003). For example, in 2004, several CBS affiliates including KCTV (a TV station in Kansas City, Missouri) ran a sting operation supported by police agents by teaming up with a website, www.perverted-justice.com. The website was exposed to potential pedophiles, and the operatives posed as adolescents, visiting chat rooms and enticing adults into meeting them for dates (McClellan, 2004). In all, 16 alleged sex predators were subsequently arrested.

Sting operations surely have some merits. For instance, crimes can be prevented by police intervention before real harm occurs (Colquitt, 2004). In addition, apprehension and prosecution of sexual criminals have become so much easier.

*Address correspondence to this author at the School of Communication and Media, 52 Hyochangwon-gil, Yongsan-gu, Sookmyung Women's University, Seoul, Korea 140-742; Tel: (82) 2-2077-7376;

Fax: (82) 2-710-9731; E-mail: jwshim @ sookmyung.ac.kr
Some studies leave room for questions regarding the effectiveness of sting operations (Langworthy, 1989), but they are supported due to these potential merits. However, a great portion of researchers object to sting operations as a legal strategy, arguing that sting operations are being conducted with the idea that those who have dangerous dispositions would be caught (Gregg, 1996; SinnottArmstrong, 1999). As a result, sting operations raise some issues on the justifiability of using bogus operations on the Internet to arrest a person expected to have a dangerous disposition. Moreover, should the legality of such strategy fall under irrefutable opposition, the next issue would concern the alternative option for inducing potential criminals. These issues at the center of the debate concerning sting operations online remain unanswered.

Previous legal cases and literature on sting operations acknowledge that one's disposition is the most essential element in determining responsibility (Sinnott-Armstrong, 1999). That is, whether one can be punished only because he seems to have a dangerous disposition is one of the core questions in the use of sting operations. However, the law does not clearly define the meaning of disposition (Gershman, 1993), as few attempts have been made to delve into the role of disposition. Since the early 1990s, psychological studies have accumulated significant knowledge on disposition. Based on the psychological findings on disposition, the present study attempts to answer the question of whether or not such disposition-oriented sting operations could be justified. This topic is important because public anxiety over sexual crimes on the Internet is rapidly increasing, yet there remains a lack of consensus in the justification of sting operation via the Internet.

\section{COURTS' RULING ON STING OPERATIONS}

Two sting operation cases were reviewed in this section to show the defendant's psychological disposition, which has 
been debated over in criminal trials and where the sting defense has become the issue.

One of the best known cases to address sting operation claims regarding illegal pornography was the case of Jacobson v. United States, 60 U.S.L.W. 4307 (1992), which involved Jacobson's possession of illegal pornographic materials (e.g., child pornography). In 1984, Jacobson ordered and received from an adult bookstore two Bare Boys magazines containing photographs of nude preteen and teenage boys. His purchase occurred before the Child Protection Act of 1984, which made it illegal to receive sexually explicit depiction of children by mail. After finding Jacobson's name in the bookstore's mailing list, the government sent several pieces of mail to him to explore his willingness to break the law. The mail included such content as a desire to promote sexual freedom through lobbies and concerns regarding censorship of sexual freedom. After 26 months of government mailings, Jacobson finally decided to order child pornography magazines. He was arrested after a controlled delivery of the ordered magazine. However, a search of his house revealed no materials other than those sent by the government (Cleary, 2000).

The Supreme Court rejected Jacobson's conviction on the premise that the defendant's ready response to these solicitations was not enough to establish beyond a reasonable doubt that he was predisposed, prior to the government acts intended to create predisposition, to commit the crime of receiving child pornography through the mails. ${ }^{1}$ The majority opinion took the position that one's disposition should be determined at the time when the police agencies made initial contact with the potential criminal. However, the Jacobson minority required an inquiry into whether or not the crime resulted from the undercover agent's actions or purely from the defendant's prior inclinations, contacts, and resources. $^{2}$ The minority opinion implied that a person who receives pornographic materials by mail would violate the law even though he does not know it is against the law to do so. Gershman (1993) argued that the minority's point is consistent with the basic principles of criminal law, which often require "a specific MENS REA for anticipatory crimes, but a more general MENS REA for the substantive crime itself." This means that "an attempt to commit a crime (which) requires a specific intent to commit the crime, whereas the actual crime itself may require no such intent" (p. 3).

Secondly, the case of United States v. Poehlman, 217 F.3d 692, (2000) is known as one of the important online sting operation claims. The defendant, Poehlman, was believed to have been induced by a female government agent through the Internet in the case (Moore et al., 2007).

"Mark Douglas Poehlman surfed the Net in search of adult comrades who share his sexual tastes. Instead, he found a federal agent posing as an adult named Sharon. Poehlman sought a relationship with Sharon, an adult, who then explicitly made sexual relations with her daughters a precondition of the relationship. Poehlman, lonely, confused, and clearly wishing to have an adult relationship, agreed to

\footnotetext{
${ }^{1}$ Jacobson v. United States, 503 U.S. 540 (1992).

${ }^{2}$ Jacobson v. United States, 503 U.S. at 550 (1999).
}

Sharon's terms and met Sharon in a hotel, where he was arrested." (Nelson \& Simek, 2000)

The Court found no evidence that Poehlman had a predisposition to commit a crime. The Court found that Poehlman was an otherwise law-abiding citizen who sought adult companionship and was lured into crossing the line between fantasy and criminality by the agent over a period of months. This decision is considered as the first federal appellate ruling that held an Internet sex investigation to be a sting operation (Nelson \& Simek, 2000).

These cases show that the courts' rulings on sting operation tend to stress dispositional aspects more than morality or justifiability of the use of inducement. In other words, the law admits that law enforcement officers can instigate or induce a person into the commitment of a crime. However, such dispositional perspective is fundamentally counterfactual because "it hinges on the questions not of what actually happened but of what would have happened if things had been different" (Sinnott-Armstrong, 1999, p. 97). This implies that the defendants would not have violated the law on the foregoing situations if the government agent had acted differently. Colquitt (2004) argued that it is ironic to observe that sting operations lead to the creation of crime and the ensnaring of the innocent people, rather than working as a fair measure in judging defendants. Feinberg (1995) also argued that under the current doctrine of sting operations, people are criminals to a certain degree because they are supposed to commit some types of forbidden acts (e.g., overtime parking).

\section{CHARACTERISTICS OF STING OPERATIONS ON- LINE}

Prior to the emergence of the Internet, sting operations had potential but specific targets. For example, the officers had Jacobson as a target to test his disposition toward child pornography. They continued to solicit Jacobson up to 26 months. ${ }^{3}$ However, sting operations through the Internet aim at unspecified individuals without specific targets, even though it is believed that people with dangerous dispositions will be caught eventually (Gregg, 1996; Sinnott-Armstrong, 1999). In addition, Internet users can change their identity and tend to behave differently on the Internet due to anonymity, one of the key characteristics of the Internet. Internet users can "adopt different personae and fantasize about doing acts that they would never do in real life" (Sinnott-Armstrong, 1999, p. 102). Thus, a desire or intention expressed online might not be "real." This means that essentially everyone on the Internet is a potential target for the sting operation by law enforcement officers at some level.

In fact, Demetriou and Silke (2003) demonstrated that a majority of Internet users easily fall into sexual temptation on the Internet. In the study, the researchers constructed a website to observe those who visited for the purposes of gaining access to legal material would also attempt to access illegal and/or pornographic material. They found that those sections offering illegal and/or deviant sexual material were accessed by a majority of visitors. They reasoned that deindividuation caused by anonymity is a psychological state

\footnotetext{
${ }^{3}$ Jacobson v. United States, 503 U.S. 540 (1992).
} 
of decreased self-evaluation, and decreased evaluation apprehension results in anti-normative and disinhibited behavior. Gregg (1996) pointed out that "caught up in the free-flowing atmosphere of the medium, individuals are prone to say things they might not say elsewhere because of the anonymity and the false intimacy of cyberspace interaction" (p. 187). As the Internet has rapidly changed the way of pornography use, the issue of sting operations online has become more complicated.

\section{LIMITS OF THE SUBJECTIVE APPROACH TO STING OPERATIONS ONLINE}

Two approaches for determining the responsibility in sting claims have been proposed so far: objective and subjective. The rationale for the objective approach is "to keep police officers from misbehaving by using too strong inducements" (Sinnott-Armstrong, 1999, p. 99). This perspective focuses on "overzealous law enforcement and limits the entrapment inquiry to the government's actions" (Tawil, 2000, p. 2377-2378). Thus, the defendant is required to prove that there is improper police inducement. Police agencies would be unable to secure a conviction unless their conduct is proper under the objective approach.

On the other hand, under the subjective approach, it is acceptable for law enforcers to set up those who are predisposed to break the law. In this case, law enforcement agencies have the burden of proof and should show that a defendant is disposed to commit the crime prior to the government operation. This approach is based on the rationale that "those with weak dispositions for crime are unwary innocents, whereas those with strong dispositions to crime are the very people who need to be found guilty and punished to prevent their crimes" (Sinnott-Armstrong, 1999, p. 99).

The problem is that the likelihood of conviction is much greater in the subjective than in the objective approach. The Supreme Court adopts five factors to assess an individual's disposition: prehistory of the defendant (e.g., criminal history); who initiates the criminal activity; whether the defendant engaged in the activity for profit; whether the defendant demonstrated reluctance; and the nature of timing of the government's inducement (Tawil, 2000). However, legal scholars point out that the definition of disposition of the law is unclear and problematic. For example, Gershman (1993) argued that the Supreme Court has never defined disposition and has not indicated when the defendant's disposition must be found to exist: at the time when the potential defendant finally commits the crime by the creation of police operation, or at the time when the government first makes contact with the potential criminal. According to Sinnott-Armstrong (1999), it does not make sense to prove a defendant's disposition in courts due to potential outcome bias. For example, the prehistory of the defendant, when portrayed vividly by prosecutors, can prejudice a jury against the defendant. This leads to outcome bias where a jury makes a decision on the case based solely on the outcome of the decision regarding the defendant's disposition. Similarly, Arkes (1989) pointed out that wise choice will not always result in superior outcomes. Criticizing the subjective approach, Gershman (1993) argued that a sting operation allows "the government to use outrageous methods to investigate crime, as long as the government (can) prove that the defendant was predisposed to commit the crime" (p. 1).

Thus, the subjective approach is prone to engender outcome bias, which is not the proper way to assess a defendant's disposition. In spite of its potential flaws, the subjective approach is applied to online sting operation cases (e.g., United States v. Poehlman, 2000). The following sections will review psychological literature on disposition and make an argument that the current subjective approach to sting operation cannot be justified.

\section{ROLE OF DISPOSITIONS IN THE LAW AND IN PSYCHOLOGY}

It is necessary to review the role of disposition to understand the controversy over online sting operations. The definition of disposition is different between law and psychology. The Supreme Court defines disposition as a defendant's criminal inclination, which is independent of inducement of the law enforcement officials. However, if a disposition is a simple inclination as the Court defines, it can be said that anyone who wants to see pornography would have a disposition to commit sexual crimes. In this sense, the Court's definition ignores the notion that a disposition is not a mere desire, proclivity, or inclination, nor is it more susceptible to suggestion (Sinnott-Armstrong, 1999).

Meanwhile, dispositional psychology has proven two essential characteristics of disposition: central dispositions are relatively stable over time and consistent across situations, and the strategy through which the most important or central disposition of people can be compared is isolated (Weaver, 2003, p. 1428). Thus, dispositional psychology defines disposition as a more or less stable and enduring organization of a person's character, temperament, and physique (Eysenck, 1990; Eysenck \& Eysenck, 1985). An individual's disposition determines his or her unique adjustment to the environment (Eysenck \& Eysenck, 1985) and "how likely the precipitating circumstances are to occur" (Feinberg, 1995, p. 158).

According to dispositional psychology, disposition interacts with the environment and varies in strength. Thus, a person may be more disposed than another to do specific acts. For example, psychopaths are more disposed to stronger stimulation. In addition, disposition is highly context-dependent. As the social cognitive theory of disposition assumes, disposition interacts with cognition and environment. It is "a self-system as the result of the interaction of the person and his or her environment, which allows self-control through self-reward and selfpunishment - a possible basis of moral behavior" (Funder, 2001, p. 204). Under this theory, one's disposition is related to behavior, which involves "an indispensable, continuous interaction between individuals and the situations they encounter" (Endler, 2000, p. 382). This interaction model provides a clue that there is a weak (or no) relationship between a disposition and a behavior when inducement is controlled.

\section{Dangerous Dispositions: Needs and Readiness to Respond}

Previous research has shown that different dispositions are related to social and sexual behavior, specifically 
criminal and abnormal behavior in relation to criminal law. One of the most commonly explored dangerous dispositions is psychoticism (Eysenck, Eysenck, \& Barrett, 1985). Psychoticism is a disposition related to social deviance, impulsive behavior, and lack of willingness to live by social rules and mores. These characteristics give psychotics difficulty in adapting themselves to a society or obtain satisfaction from moderate stimuli. Weaver, Brosius, and Mundorf (1993) stated that "psychotics prefer media content involving deviant and nonconforming themes that result in a physically stimulating experience" (p. 308). Psychotics do not prefer situational comedy on TV or comedy movies but prefer horror movies (Weaver, 1991). Zillmann and Weaver (1997) also found that after watching gratuitously violent films, psychotics accept violence as a means to resolve conflict.

Psychopathy is also frequently used to assess dangerous disposition. Hare (1970, 2003) presented four characteristics of psychopaths: cold affect, antisocial behavior, interpersonal manipulation, and impulsive thrill seeking. Psychopaths avoid routine and boredom, and continually pursue extra stimulation. Given that psychopaths have relatively lower levels of cortical arousal and a chronic need for stimulation, any given intensity of stimulation would be subjectively less intense to a psychopath than to others (Hare, 1970). Therefore, psychopaths pursue any type of sensory input that has a positive effect and can maintain their optimal level of arousal. A recent study finds that psychopaths prefer antisocial entertainment activities (e.g., aggressive films, playing and watching violent sports, violent video games, and Internet use for pornography and hacking) (Paul, 2009; Williams, McAndrew, Learn, Harms, \& Paulhus, 2001). Dorr (1998) found a high correlation between psychopathy measure and pedophilic tendency, such that majority of pedophiles are psychopathic or exhibit psychological characteristics of psychopathy to a significant degree.

How those who have dangerous dispositions use the Internet has rarely been addressed. However, psychopaths utilize the Internet to feel optimal levels of arousal. Considering that psychopaths are hardly satisfied with moderate level of stimuli, they might try to pursue more aggressive, violent, or sexually bizarre stimuli that others would most likely avoid. Paul (2009) showed that the subjects' level of psychopathy significantly adds to the predictability of regular Internet pornography (e.g., group sex, lesbian, amateur, ejaculation) use and arousal. The present study finds that those who have higher psychopathy levels are more likely to use both standard fare and specialized pornographic Internet content (e.g., homosexual males, overweight people), whereas those who have lower psychopathy levels are only more likely to report arousal in response to specialized content. Those who have high levels of psychopathy do not respond to regular or popular Internet pornography. Instead, they are more likely to consume and get aroused by extreme pornography that less psychopathic people generally avoid.

These findings simply state that as long as opportunities are provided, those with dangerous dispositions will more likely be caught by sting operations on the Internet. Given that disposition refers to needs and readiness to respond
(Oliver, 2002), people with dangerous dispositions pursue stimuli that fulfill their needs and are prepared to respond when the stimuli fit their requirements. If the goal of sting operations through the Internet is to arrest dangerous potential criminals, law enforcement officials must subsequently adopt strong inducement techniques. However, the strength of an inducement should depend on how many and which people would be affected rather than on how it affects a particular defendant (Sinnott-Armstrong, 1999).

\section{CONCLUSION}

The present study was conducted to clarify the controversy over sting operations online from a dispositional psychological perspective, focusing on the role of disposition in criminal acts. In particular, it challenged the dominant tendency that the Court relies on the subjective approach in the judging of responsibilities of sting operations. As long as criminal defendants are proven to have been induced by certain governmental persuasion or deceit (e.g., sting, scam), the defendant has no liability for the crimes he committed. However, previous cases (e.g., Jacobson v. United States, and Poehlman $v$. United States) have shown that the underlying rationale of sting operation is that those with dangerous dispositions are potential criminals and should, therefore, be arrested before they commit crimes.

A sting operation entails either an objective approach or a subjective approach. The former is based upon the strength of law enforcement inducement, and the latter is based on the disposition of a defendant. From the Sorrells case $\mathrm{c}^{4}$, which is known as one of the first sting operation claims, the idea of a sting operation has been dominated by the subjective approach. According to Frazier (1994), a sting operation is "when you, the big, bad policeman, put evil thoughts into the mind of an otherwise innocent, law-abiding citizen and so coerce him to commit a crime for which you can then arrest him" (p. 134).

Through the review of psychological literature, the present study found some flaws in the legal cases on sting operations. First of all, the legal definition of disposition does not clearly describe it as a simple proclivity or inclination. Moreover, such unclear definition of disposition might provide room for biased impression in legal cases. For example, even without good evidence, the prejudices of juries or judges can affect their views of a defendant's disposition (Sinnott-Armstrong, 1999). Without considering the interactions between disposition and environment and cognition, any outcome could bias judgmental decision. As long as the Supreme Court is prone to adopt the subjective approach, in which disposition is separated from the interaction with the environment and cognition, significant biases could still be involved. In addition, the legal definition does not consider interactions of disposition with the environment or the context. Psychological findings showed that when the environment or context is controlled, disposition would not be expressed. That is, if there are no intentional inducements working as an environmental factor by law enforcement officers, dangerous dispositions would not be associated with dangerous behaviors. In this sense, the

\footnotetext{
${ }^{4}$ Sorrells v. United States, 287 U.S. 435 (1932)
} 
present study argues that the subjective approach is difficult to be justified.

The present study finds that the subjective approach to sting operations is directly applied to online sting operations. The Internet is an interface between fantasy and reality. As Abbott (2002) said, "Based on the dearth of case law relating successful defense strategies, it is reasonable to assume that exceptional conviction rates will continue. Fueled by success, law enforcement will enhance its proactive efforts." What somebody says on the Internet "can create misleading suspicions about what he would do" (Sinnott-Armstrong, 1999, p. 100). The subjective approach ignores the point that the defendants would not have violated the law if repeated and persistent solicitation by the agent did not take place.

In sum, taking advantage of the ease of the Internet needs more caution because everyone on the Internet is regarded as a potential criminal under current sting operation claims. This is the time to revisit the sting operation claims to devise ways to face sexual criminals on the Internet.

\section{ACKNOWLEDGEMENT}

This research was supported by the Sookmyung Women's University Research Grant 1-1003-0377.

\section{REFERENCES}

Abbott, P. G. (2002). Internet Sexual Entrapment: The Poehlman Decision and Beyond. Retrieved April 21, 2005, from http://gsulaw.gsu.edu/lawand/papers/fa02/abbott/

Arkes, H. R. (1989). Principles in judgment/decision making research pertinent to legal proceedings. Behavioral Science and the Law, 7, 429-456.

Beech, A., Elliott, I., Birgden, A., \& Findlater, D. (2008). The internet and child sexual offending: A criminological review. Aggression and Violent Behavior, 13(3), 216-228.

Cleary, R. C. (2000). The Sting of Entrapment. Retrieved April 20, 2005, from http://www.suite101.com/article.cfm/criminal_law/42164/2

Colquitt, J. A. (2004). Rethinking entrapment. American Criminal Law Review, 41, 1389-1437.

Demetriou, C., \& Silke, A. (2003). A criminological internet sting. British Journal of Criminal, 43, 213-222.

Dorr, D. (1998). Psychopathy in the pedophile. In T. Millon \& E. Simonsen (Eds.), Psychopathy: Antisocial, Criminal, and Violent Behavior (pp. 304-320). New York: Guilford Press.

Endler (2000). The interface between personality and cognition. European Journal of Personality, 14, 377-389.

Eysenck, H. J. (1990). Biologicla dimensions of personality. In L. Pervin (Ed.). Handbook of Personality: Theory and Research (pp. 244276). London: The Guilford Press.

Eysenck, H. J., \& Eysenck, M. W. (1985). Personality and Individual Differences. New York: Plenum.

Eysenck, S. B. G., Eysenck, H. J., \& Barrett, P. (1985). A revised version of the psychoticism scale. Personality and Individual Differences, 6(1), 21-29.

Feinberg, J. (1995). Instigating the Unpredisposed: Bad Luck in Law and Life. In W. Sinnott-Armstrong (Ed.), Modality, Morality, and
Belief: Essays in Honor of Ruth Barcan Marcus (pp. 152-173). NY: Cambridge University Press.

Frazier, S. K. (1994). The Sting Book: A Guide to Setting up and Running a Clandestine Sting Operation. Springfield, IL: C.C. Thomas.

Funder, D. C. (2001). Personality. Annual Review of Psychology, 52, $197-$ 221.

Gershman, B. L. (1993, January, 27). Entrapment revisited. New York Law Journal, p. 1.

Gregg, J. (1996). Caught in the Web: Entrapment in Cyberspace. Hastings Communications and Entertainment Law Journal, 19, 157-197.

Hare, R. D. (1970). Psychopathy: Theory and research. New York: John Wiley \& Sons, Inc.

Hare, R. D. (2003). The Hare Psychopathy Checklist - Revised (PCL-R) (2nd ed.). Toronto, Ontario: Multi-Health Systems.

Hay, B. (2005). Sting operations, undercover agents, and entrapment. Missouri Law Review 70, 387-431.

Jones, M. (July 22, 2007). How can you distinguish a budding pedophile from a kid with real boundary problems? New York Times, Magazine Section, 33-39, 56, 58-59.

Krone, T. (2004). A typology of online child pornography offending. Trends and Issues in Crime and Criminal Justice, 279, 1-6.

Langworthy, R. (1989). Do stings control crime? An evaluation of a police operation. Justice Quarterly, 6(1), 27-45.

McClellan, S. (2004). Controversy surrounds sex-predator sting. Broadcasting \& Cable, 134(12), 14-17.

Moore, R., Lee, T., \& Hunt, R. (2007). Entrapped on the Web? Applying the entrapment defense to cases involving online sting operations. American Journal of Criminal Justice, 32, 87-98.

Nelson, S. D., \& Simek, J. W. (2000). Entrapment on the Net: 9th Circuit draws the line. Retrieved April 20, 2005, from http://www.senseient.com/bytesinbrief/bytes.asp?page=August_20 00.htm

Oliver, M. B. (2002). Individual Differences in Media Effects. In J. Bryant \& D. Zillmann (Eds.), Media Effects (2 ed., pp. 507-524). Mahwah, NJ: Lawrence Erlbaum.

Paul, B. (2009). Predicting Internet pornography use and arousal: The role of individual difference variables. Journal of Sex Research, 46(4), 344-357.

Quayle, E., \& Taylor, M. (2003). Model of problematic Internet use in people with a sexual interest in children. CyberPsychology \& Behavior, 6(1), 93-106.

Sinnott-Armstrong, W. (1999). Entrapment in the Net? Ethics and Information Technology, 1, 95-104.

Tawil, D. D. (2000). "Ready? Induce, Sting!": Arguing for the government's burden of proving readiness in entrapment cases. Michigan Law Review, 98, 2371-2394.

Weaver, J. B. (1991). Exploring the links between personality and media preferences. Personality and Individual Differences, 12(12), 12931299.

Weaver, J. B. (2003). Individual differences in television viewing motives. Personality and Individual Differences, 35(12), 1427-1437.

Weaver, J. B., Brosius, H., \& Mundorf, N. (1993). Personality and movie preferences: A comparison of American and German audiences. Personality and Individual Differences, 14(2), 307-315.

Williams, K. M., McAndrew, A., Learn, T., Harms, P., \& Paulhus, D. L. (2001). The Dark Triad Returns: Entertainment Preferences and Antisocial Behavior Among Narcissists, Machiavellians, and Psychopaths. Paper presented at the $109^{\text {th }}$ annual convention of the American Psychological Association, San Francisco.

Zillmann, D., \& Weaver, J. B. (1997). Psychoticism in the effect of prolonged exposure to gratuitous media violence on the acceptance of violence as a preferred means of conflict resolution. Personality and Individual Differences, 22(5), 613-627. 